\title{
VARGAS E SUA HERANÇA: a importância de se discutir a década de 1950 e a obra de Ângela de Castro Gomes
}

\author{
GOMES, Ângela de Castro (org.). Vargas e a crise dos anos 50. 3. ed. Rio de \\ Janeiro: Ponteio, 2011.
}

\section{Felipe de Sousa Lima Vasconcellos*}

É por construir obras de referência como Vargas e a Crise dos anos 50, que Ângela de Castro Gomes é reconhecida como um dos principais nomes da historiografia nacional quando se trata do período getulista. A obra, composta por artigos escritos por estudiosos de várias áreas do conhecimento, trata dos anos 1950 por meio de uma perspectiva plural. Lançada pela primeira vez em 1994, chega a sua terceira edição, para a satisfação de quem busca abordagens diferenciadas acerca desse período conturbado e importante da História do nosso país.

Desde que lançado, Vargas e a crise dos anos 50 foi reverenciado com elogios de diferentes estudiosos da História do Brasil e do período varguista, em especial. Época de grandes realizações e transformações em diversos setores de nossa sociedade, a Era Vargas é comumentemente trazida à tona ao se discutir sobre temas centrais para os rumos do país. Em áreas como educação, saúde e economia ainda hoje vemos os reflexos dos quinze anos em que Getúlio Vargas esteve à frente do poder. Seu legado é um dos temas centrais do livro, cuja discussão é de grande importância para a conjuntura política atual. Pela abrangência e singularidade nas abordagens, o livro é capaz de despertar interesse de vários pesquisadores, quase vinte anos após seu lançamento.

O suicídio de Vargas é corriqueiramente interpretado como um dos acontecimentos mais traumáticos de nossa História. Podemos dizer que esse fato teve repercussões em todas

\footnotetext{
* Mestrando em História pela Universidade do Estado de Santa Catarina. E-mail: felipe.vasconcellos@hotmail.com.br
} 
as áreas da sociedade brasileira. E o livro organizado por Ângela de Castro Gomes faz uma abordagem tão diversa quanto os impactos deste acontecimento. Há contribuições de historiador, jornalista, economista, cientista político e arquivista, que lançam um olhar sobre a crise dos anos 50 sob diferentes ângulos, possibilitando aos leitores abarcar a complexidade do fato.

As diversas fontes pesquisadas pelos autores dos artigos - jornais, revistas, arquivos de partidos políticos, minissérie e mesmo os arquivos pessoais do ex-presidente - fazem com que a obra seja uma das mais completas a respeito do assunto. Contudo, as abordagens não se restringem ao suicídio e à crise instaurada: lançada em 1994, a obra traz importantes discussões acerca de conceitos fundamentais para a construção democrática - nacionalismo, trabalhismo, imperialismo, populismo - num momento em que o impacto gerado pelo primeiro impeachment de um presidente no país era grande.

Ao discorrer sobre a cobertura da imprensa na crise instaurada no país após o atentado da Rua Toneleros, Alzira Alves de Abreu e Fernando Lattman-Weltman não se limitam a simples descrições das notícias veiculadas pelos principais jornais, mas abordam a imprensa como construtora do próprio fato histórico. Debruçando-se sobre aqueles dias conflituosos de nossa política com uma sensibilidade admirável, os autores trazem à tona uma questão fundamental para se pensar os dias atuais: a relação entre imprensa e poder.

Os motins populares que se seguiram ao suicídio de Vargas têm um lugar de destaque na obra. Jorge Ferreira é autor do capítulo “O Carnaval da Tristeza: os motins urbanos do 24 de agosto”. Esse especialista na temática do populismo demonstra que a morte do presidente foi um trauma ao mesmo tempo político, social e simbólico. Lança bases também para uma interpretação inovadora sobre a conjuntura política da época: diferentemente do comumente aceito, afirma que não foi Vargas - ou melhor, não apenas ele - que atrasou o golpe militar em dez anos, mas sim a reação popular à morte do presidente. Colocando as classes mais baixas de nossa sociedade como protagonistas políticos, Ferreira dá uma bela contribuição aos estudos sobre uma cultura política que ainda busca integrar toda a população ao cenário político.

Os projetos de leis e as atuações de órgãos criados no segundo governo Vargas são utilizados por Maria Antonieta Leopoldi para discutir o posicionamento do presidente frente à polarização característica do período da Guerra Fria. Figura dúbia, visto por uns como entreguista e pelos mais conservadores como nacionalista extremo, Vargas sintetizava em sua figura as concepções econômicas daqueles tempos. Ao debater sobre o "caminho do meio", almejado pelo presidente, Leopoldi fornece subsídios para que possamos pensar a herança 
desse que foi o governante do país por mais tempo, e que marcava as posições políticas e econômicas de sua época: era-se contra ou a favor do varguismo nos anos 1950.

À época do lançamento do livro, comemoravam-se 40 anos da criação da Petrobrás e da Eletrobrás. Não é sem motivos que a temática da soberania nacional na área energética tenha ganhado destaque nas páginas do livro. O livro fornece importantes subsídios para abordar as relações entre o governo, empresários e burguesia industrial ao debater sobre as dificuldades encontradas pelo presidente Vargas em colocar em prática sua política econômica. Não se eximindo de debater sobre os rumos da nossa política econômica, a obra possibilita inclusive que pensemos acerca do peso que o poder econômico tem nas decisões governamentais.

A organizadora da obra, Ângela de Castro Gomes, assina o artigo “Trabalhismo e democracia: o PTB sem Vargas”. O artigo apresenta uma pesquisa sobre um partido político permeada de abordagens sobre a cultura política de então, mas o foco é no significado do trabalhismo e do varguismo na política nacional. O artigo mostra também como o partido herdeiro da figura de Vargas teve que se reestruturar para poder manter-se, num jogo político onde o carisma pessoal é muitas vezes mais impactante aos eleitores do que projetos ou ideologias.

Outra questão presente no livro, no artigo de autoria de Suely Braga da Silva, diz respeito ao legado documental de Vargas. O período de seu governo constitui-se em um dos mais férteis de nossa história em termos de fontes disponíveis. O acervo pessoal de Vargas é preservado e colocado à disposição para pesquisas pelo CPDOC - Centro de Pesquisa e Documentação de História Contemporânea do Brasil da Fundação Getúlio Vargas. A trajetória desse acervo e a figura de Alzira Vargas, filha de Getúlio, são debatidas pela autora, que ainda denuncia um obstáculo a ser perpassado pelos especialistas: as dificuldades de se encontrar e estudar fontes sobre o período republicano do país.

São obras dessa profundidade que, mesmo não possuindo uma linguagem estritamente acadêmica, nos mostram que um acontecimento político pode modificar os rumos de toda uma sociedade, e mais que isso: permite mostrar mais uma vez aos historiadores que a política integra e marca de forma indelével todas as áreas do social, e não é a elas subordinada, como alguns insistem em afirmar. 